\title{
Educational Resources of Cartography and Geography in the IGN of Spain
}

\author{
Ana Velasco Tirado ${ }^{\text {a }}$, Celia Sevilla Sánchez ${ }^{\text {b }}$ \\ ${ }^{a}$ Centro Nacional de Información Geográfica (Instituto Geográfico Nacional), avelasco@fomento.es \\ ${ }^{b}$ Centro Nacional de Información Geográfica (Instituto Geográfico Nacional), cssanchez@fomento.es
}

Keywords: Education, Resources, Atlas, Maps, Interactive, Game, Cartography, Geography.

The National Geographic Institute (Instituto Geográfico Nacional, IGN) of Spain is the state mapping agency in charge of the Cartography, Photogrammetry, Astronomy and Geophysics of the country.

The IGN commitment to the education of children and young adults in Earth sciences comes from decades ago. Many educational resources made in the last ten years, related to geography, cartography and Earth science are available in both digital and physical formats.

Educa IGN [1] is the section of IGN main website [2] that hosts the digital educational resources. In 2019, this site has been updated, not only in its contents but also in its appearance and usability. It is possible to filter resources by type, subject and education level.

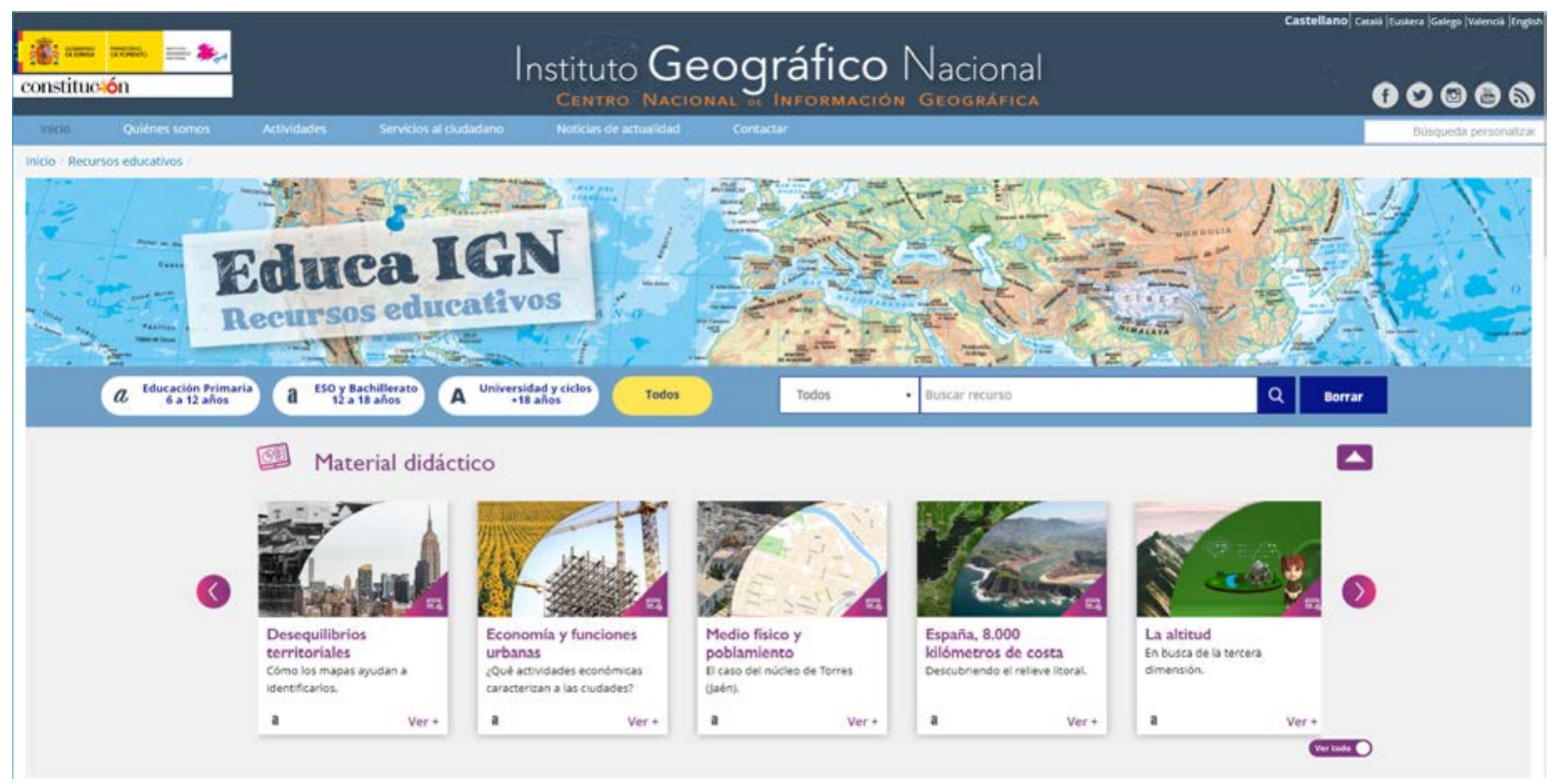

Figure 1. Educa IGN site (2019).

The different types of educational resources at Educa IGN are:

- $\quad$ Teaching materials: Contents specifically designed for educational purposes:

o Interactive maps, for students between 12 and 16 years old, about Human Geography topics, like territorial imbalance [3], economy and urban functions [4], physical environment and settlement [5] or Spanish coastal features [6].

o Descubre el territorio (Discover the territory) [7]: new materials for children between 10 and 16 years old. They combine theoretical explanations with quizzes for evaluating new knowledge while playing, with a youthful air and characters with which students can empathize. The contents are about altitude, reading a map, cartographic symbols, place names, draw a map, orientation, height difference, the city and coastal relief.

o España a través de los mapas (Spain throug maps) [8]: a cartographic complement to the geography textbooks of high school.

o Mi amiga la Tierra (My friend the Earth) [9]: the first steps for little children to discovering the world. 
- Atlas didáctico de América, España y Portugal (Teaching atlas of America, Spain and Portugal) [10]: geography of these three areas of the world for high school students.

o La población en España (The population of Spain) [11]: human geography Maps of Spain. For primary school to university.

- Atlas digital de Caminería Hispánica (Digital Atlas of Hispanic Roads) [12]: Atlas of the historical roads in Spain, America and The Philippines.

o Conceptos cartográficos (Cartographic concepts) [13]: manual with general concepts about cartography.

o Tu amigo el mapa (Your friend the map) [14]: digital book with the main basic concepts about maps for children.

Maps:

- National Atlas of Spain (Atlas Nacional de España, ANE) [15], whose last version, "España en mapas. Una síntesis geográfica" [16], was published in 2018. It is a compendium of maps, charts, reports, tables and photographs that aims to depict the detailed human and physical geography and history of the whole of Spain.

- General physical and political maps of Spain, Europe and the world for education.

- General physical and political mute maps of Spain, Europe and the world for education.

Videos:

Educational videos [17] about Geography and Cartography. Some of them are cartoons and others are narrated by experts from different thematic areas of IGN. They are about Global Navigation Satellite System (GNSS), cartographic projections, reading a map, rural landscapes, Photogrammetry, Light Detection and Ranging (LiDAR), earthquakes and tsunamis, volcanoes, among others.

Games:

- Online puzzles of physical and political geography of Spain and the world in 2D and 3D (virtual globe).

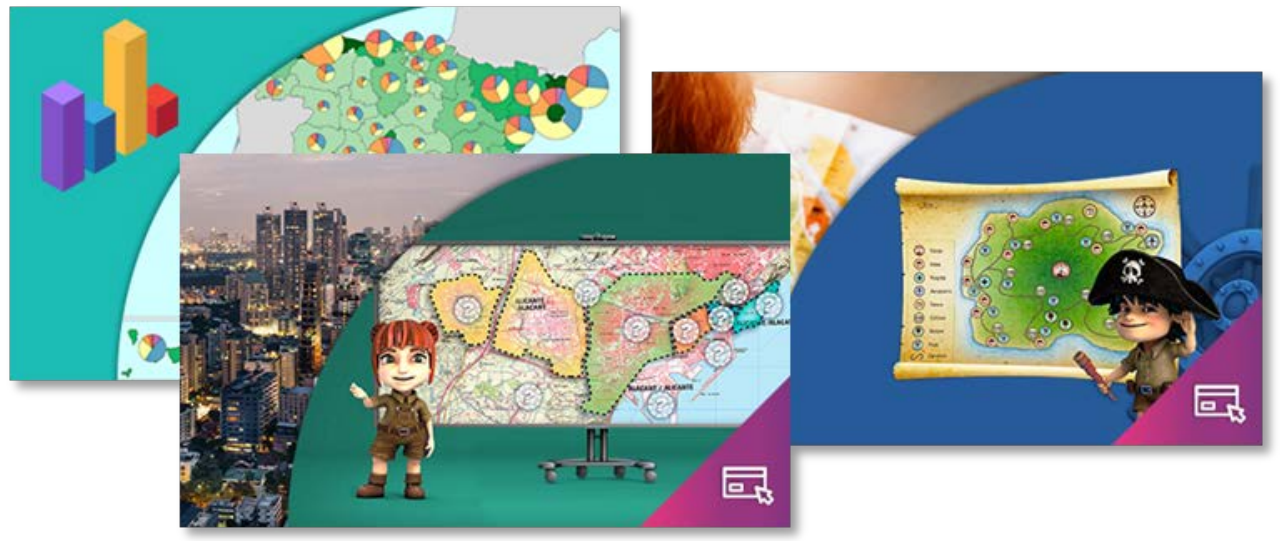

Figure 2. Some of the digital educational resources of the IGN of Spain.

Regarding the distribution of these resources, Centro Nacional de Información Geográfica (National Center of Geographic Information, CNIG) is the organization in charge of the distribution and the marketing of the products made by the IGN of Spain. The educational resources are published in digital format and, as well as most of the products of IGN, they are under a license [18] which is compatible with Creative Commons Attribution CC-BY 4.0. Therefore users (editorial companies, teachers, etc.) can use IGN maps and materials for textbooks only by referring to the appropriate credit.

There are also physical materials, as maps, books and puzzles, available in our shops all over Spain or at the Virtual Shop of CNIG [19].

For the development of the educational resources, IGN of Spain count on the support of teaching Earth science experts, among others, with the Spanish Association of Geography, the School of Engineering in Geomatics and Topography from the Polytechnic University of Madrid and the Spanish Foundation for the Science and Technology from the Government of Spain.

Regarding dissemination, several activities are carried out by the IGN of Spain. Every year, 3700 high school and university students visit our facilities: the Royal Astronomical Observatory of Madrid, the map showroom, the 
geophysics observatory of Toledo and the headquarters of the IGN, to see the daily work of hundreds of cartographers. As well as organizing conferences and workshops about Volcanology, Photogrammetry or Astronomy in events, like the Science Week or the Book Fair of Madrid.

The relationship with our collaborators and the face-to-face activities allow us to know the impact that our resources have on the educational community. In addition, the IGN collect their feedback and try to satisfy their needs by adapting its educational contents to the curriculum established in the current Spanish education law.

According the website statistics, Educa IGN has about 52000 unique page visited per year (4,000 of average per month). Most of the users are from Spain, but there are a significant number of accesses from other Spanish-speaking countries, like Argentina or Colombia. 


\section{References:}

[1] http://www.ign.es/web/ign/portal/recursos-educativos

[2] http://www.ign.es

[3] https://www.ign.es/recursos-educativos/desequilibrios-territoriales/index.html

[4] https://www.ign.es/recursos-educativos/economia-funciones-urbanas/index.html

[5] https://www.ign.es/recursos-educativos/medio-fisico-poblamiento/index.html

[6] https://www.ign.es/recursos-educativos/relieve-costa/index.html

[7] https://www.ign.es/recursos-educativos/descubre-territorio/index.html

[8] https://www.ign.es/espmap/

[9] https://www.ign.es/web/resources/cartografiaEnsenanza/flash/mi_amiga_la_tierra/homeTierra.html

[10] https://www.ign.es/atlas_didactico/

[11] https://www.ign.es/pobesp/

[12] https://www.ign.es/atlasCamineria/

[13] https://www.ign.es/web/resources/cartografiaEnsenanza/conceptosCarto/concepCarto_18.html

[14] https://www.ign.es/web/resources/cartografiaEnsenanza/amigoMapa/tuamigoelmapa.html

[15] http://www.ign.es/web/ign/portal/ane-area-ane

[16] http://atlasnacional.ign.es

[17] https://www.youtube.com/playlist?list=PLLemwiHg3TamcBrBcJrdxyOmTwPbV2lbp

[18] http://www.ign.es/resources/licencia/Condiciones_licenciaUso_IGN.pdf

[19] https://www.cnig.es 